\title{
A Watery Road to Critical Thought: Oceanography's Place in Science Education
}

\author{
BY TOM GARRISON
}

My greatest professional joy for more than three decades has been teaching general oceanography to students not majoring in science. Science education and science students have changed substantially over that time-professors have become more specific and detailed in their coverage of our field, but our students are less aware of the basic facts needed to assimilate the information.

Many of my colleagues wring their hands and deplore the inattention and lack of focus of students in their lecture

ments, the popularity of state lotteries, the proliferation of fad diets, astrology, and superstitions of all sorts. Never forget that many of these students will vote in upcoming elections - they need education in the basic sciences more than any generation in recent history, and you're in a unique situation to provide some of it. No introductory science course is more grandly interdisciplinary, or inherently interesting, or amenable to spectacular images than basic oceanography. Here is a framework in which we

\section{No introductory science course is more grandly} interdisciplinary, or inherently interesting, or amenable to spectacular images than basic oceanography. Here is a framework in which we can teach scientific logic and keep people awake!

halls. A downward spiral is at work: Why should I prepare brilliant lectures if the students are asleep, or absent, or checking for phone messages while I explain the wonders of my specialty?

My message: Get a grip! The results of 25 years of inconsistent science education surround us, clearly evident in such things as the success of unproven and sometimes dangerous herbal supple- can teach scientific logic and keep people awake! For a generation of students who don't know the causes of the seasons, who think all dolphins are cuddly and intelligent, who may believe Earth is about 10,000 years old, and who sometimes view organic evolution with grave suspicion, we may offer a last chance to invite critical thought.

We face three high hurdles:

\section{GEOGRAPHICAL AWARENESS}

Many of our freshmen and sophomores do not understand basic geographic relationships. If you lecture in an introductory class, don't assume your students will connect a description of the geology of Iceland with the position of that country on the mid-Atlantic ridge. Locations of land masses and ocean basins? Nearly all students can identify the Pacific Ocean (at least on my coast), but often don't know where the Mediterranean Sea or Greenland is situated. Though most of their clothing was made in China, they will struggle to locate the world's most populous country on a globe. Latitude and longitude? They don't have the foggiest idea where the prime meridian and equator intersect. The globe itself is a mystery-ask an average student to propose an airliner route from Los Angeles to London, and he'll route you over New York City every time. Give him a string to stretch between those two cities and watch his eyes widen.

This is a reality, and our reaction as professors should not be dismissive or bitter. It means we must teach geography as we teach oceanography. I have a

Tom Garrison (tsgarri@attglobal.net) is Marine Science Professor, Orange Coast College, CA. 
high-definition Robinson projection of the world (which is less distorting than our customary Mercator presentation) on perpetual cue, ready to project to demonstrate geographic relationships. In lecturing to large classes, I fix my descriptions in position-I show ideas in geographical context. For example: Draw a latitude line connecting southern Hudson's Bay to London, and integrate that with west-to-east wind direction at that latitude. Now review the thermal response of dirt vs. liquid water to an input or removal of heat. Thanks in part to differential thermal properties and the Gulf Stream, there are no polar bears in the streets of London!

\section{HISTORICAL AWARENESS}

If you want to lose your appetite before lunch, ask a student in your introductory class to place the following in chronological order: the construction of the first pyramids, the American Civil War, the prime period of the Alexandrian Library, and the efforts of Christopher Columbus. For that matter, ask her if Columbus discovered America? (Even when I show detailed charts of Columbus's four voyages, and assure my students that a nondiscovery question will be on the next exam, about 12 percent of them insist on believing Columbus discovered America.) Alfred Thayer Mahan's influence on sea power and his monumental effects on the history of the nineteenth and twentieth centuries? The contributions of Wyville Thomson and John Murray? Matthew Maury? John Rhyther? Names to be memorized and forgotten.

Again, reality must not breed contempt. If history has not interested our students in their secondary education, it certainly can in the university. Again, context is the key. The word "oceanography" was invented in a pub in Edinburgh, partly as a way for an old prof and young lion to escape the boredom and routine of departmental politics and get the hell out of town. Tell their story. The Vikings “discovered” North America, but their colony was weakened by changing climate and extinguished from with- science-student's mind, logic is easily trumped by mystery.

There's no sense fighting a frontal battle. A flanking movement using the beauty of the scientific method will do the trick, but never approach the discussion with the "curiosity $>$ observation $>$ hypothesis $>$ experiments $>$ theory $>$ law" progression. They've suffered

\section{...teaching the application of scientific logic in everyday life has never been more important. Oceanography is the best possible vehicle for this task.}

in by mass murder. Tell that story. Maury left the Union Navy during the Civil War, ran blockades for the Confederates, and resumed his post in the United States Navy after the cessation of hostilities. Tell his story.

\section{LOGICAL AWARENESS}

The relationship between cause and effect seem comfortable to us, but don't be so sure about those undergraduates sitting out there. Thermodynamic irrationality is rampant! They know that if you take heat out of water, it will get colder. Now ask for a show of hands-how many students think hot water freezes faster than cold? (You'll be astonished at the pervasiveness of this idea.) Draw clear graphs, explain the latent heat of fusion, take the freezing process step-by-step, and show how the heat added to water by the water heater must be removed by the refrigerator before the temperature of the water ends up where it started! Step by step. They will understand, but only half their brain will be with you-they suspect some sort of "trick." In the beginning- through this a dozen times - with the same ineffective result-and you won't be able to make it work for them either. Instead, grab them where it causes the greatest pain: In their cell phones! Have them imagine their cell phone suddenly stops working (a galvanizing horror)! Their road to understanding begins with the single most powerful word in scientific logic: WHY? The unstated implication is that there is a discernible reason for this failure-the dead telephone is not simply the whim of the Cell Phone gods, and the student's intimate relationship with all cell phones has not ended forever. Next, ask the group to propose some causes: Battery dead? Telephone bill not paid? Component failure inside? Prof-activated radio-frequency jammer? Now invite them to devise a test for each possible failure (switching batteries, paying the telephone bill, trying a new internal chip, going outside), trying one at a time until the problem is found. Tell them that some of the best scientists you know are the folks who diagnose and repair modern automobiles, HVAC 
(heating, ventilating, and air-condition) units, and computers- those technicians proceed one logical step at a time.

I find it frustrating that so many of my students falsely claim to be "unscientific." Their VCRs flash "12:00," they don't know how a satellite stays in orbit, the relationship between tires and a wet vs. dry road is often beyond their comprehension. But they will always ask "WHY" when something important stops working-again implying the existence a powerful (and, for us teachers, exploitable) cause-effect relationship. To posit a cause implies a solution can be found. They run mental experiments continuously: "Which way should I go home today-there's road construction down the street, so if I go that way....” They don't travel the same route just be- cause they always have. They're scientists and don't realize it.

\section{A SOLUTION?}

No one learns anything without being interested in the subject. Our first task in undergraduate instruction is to generate interest. "But," you say, "storytelling cuts into the time I have to explain the details." But what good are details not learned and not applied. Balance is clearly important; a good story has its place.

The overriding issue in science education is the application of logic. It is the beauty of the process: the search for, and minimization of, experimental error. When you discuss Coriolis effect, talk about how one might detect it and verify its operation, then give practical examples. Controversy about things like the effects of cleaning up oil spills, how much mercury-laced seafood one can safely ingest, or the progress of global warming can be approached in an experimental error discussion. Here's the heart of what we do-using oceanography as an especially interesting way to explain how the application of scientific logic and the extension of human senses tries to find order in chaos. The crucial "so what" follows the data.

In my midshipman days, I briefly served on a nuclear submarine whose motto was "Ut veniant omnes"—bring 'em on. Aggressive concern for teaching the application of scientific logic in everyday life has never been more important. Oceanography is the best possible vehicle for this task. Bring 'em on, and teach 'em oceanography while you teach 'em to think! 函

\section{Oceanography MANUSCRIPT SUBMISSION}

\section{Objective of Oceanography}

Oceanography is a valuable resource for the oceanographic community. The magazine presents significant research programs, noteworthy achievements, exciting new technology, and articles that address public policy and education and how they are affected by science and technology. The Oceanography Society (TOS) believes that this high-quality periodical can provide information to government agencies and legislatures.

\section{What Gets Our Attention}

- Brief Articles • Book Reviews • Interviews • Commentaries

\section{Language Style}

Oceanography is a scientific magazine, not a technical journal. The desired writing style is less technical and more compact than that typically used in scientific papers. Strive for clarity and simplicity. Target your article to graduate students, professional oceanographers of all traditional disciplines, and other scientifically literate audiences. Avoid technical or mathematical jargon. Write captions so that readers can get the main points of the manuscript by perusing them.

\section{Approximate Length Limitations}

- Feature Articles: 10-12 double-spaced pages; 4-5 figures.

- Review and Comment Pieces: 5-8 double-spaced pages; 2-3 figures.

- Other articles (e.g., news and information, meeting reports, book reviews) should be as concise as possible. Meeting reports should describe goals, activities, and accomplishments; not agendas, programs, and attendance.

\section{Publication Charges}

Oceanography does not require authors to pay page charges or costs for fourcolor reproduction of figures and graphics. However, to offset production costs, a modest fixed charge per article $(\$ 500)$ has been established for those articles published as part of the regular (i.e., unsponsored) section of the magazine. Contact TOS at info@tos.org for more information. 